\title{
Airways and vascular remodelling in asthma and cardiovascular disease: implications for therapeutic intervention
}

\author{
Held in Napa, California, USA, May 1993.
}

\author{
J. Black, C. Page*
}

\begin{abstract}
Vascular diseases and asthma are two common conditions associated with considerable morbidity and mortality. Both are chronic, each has an inflammatory component, both are accompanied by remodelling of hollow tubes and both are amenable to early intervention. Those working in cardiovascular diseases have already made significant advances in terms of understanding the pathophysiology and the need to conduct large scale multicentre trials to address simple but pivotal questions about altering outcomes. Those of us who work in the respiratory field lag behind.
\end{abstract}

A meeting was held in the Napa Valley, California, in May 1993, to bring together basic scientists and clinicians from each of these research fields, in order to address the similarities and differences between asthma and vascular diseases. The meeting was challenging, and thought provoking, and highlighted a number of similarities between asthma and vascular diseases. It also left those of us working in the respiratory field with a major worry - how little we know about the lesion in asthma. The meeting was held over two days. The first day was devoted to basic science, and the second to therapeutic intervention and the design of large multicentre trials to consider the impact of treatment on disease progression.

We considered (in both diseases) aspects of the pathological changes and the mechanisms contributing to the remodelling which occurs. These were addressed in studies carried out using both in vivo and in vitro experimental techniques. In particular, the regulation of growth of airway and vascular smooth muscle, in addition to the role this plays in altered in vivo and in vitro reactivity was discussed. We summarized the similarities and differences between asthma and vascular disease (table 1).

On the second day, we considered the effect of specific therapeutic intervention in asthma and the effects of this on structural changes. A particular highlight was the final presentation by Gresele on the considerable progress made by those in the cardiovascular area in the design and successful execution of large multicentre clinical trials, which posed very simple questions to huge numbers of patients. Our cardiovascular colleagues expressed some dismay over the fact that we in the respiratory field could not seem to agree on a definition of

Correspondence: *King's College London, Biomed. Sciences Dkv., Pharmacology Group, Manresa Road, London SW3 6LX.
Table 1. - Similarities and differences between asthma and vascular disease

\begin{tabular}{|c|c|}
\hline Vascular diseases & Asthma \\
\hline $\begin{array}{l}\text { 1. Risk factors, e.g. } \\
\text { familial and environ- } \\
\text { mental }\end{array}$ & $\begin{array}{l}\text { Risk factors, e.g. } \\
\text { familial and environ- } \\
\text { mental }\end{array}$ \\
\hline $\begin{array}{l}\text { 2. Inflammatory infiltrate, } \\
\text { no eosinophils }\end{array}$ & $\begin{array}{l}\text { Inflammatory infiltrate, } \\
\text { eosinophils present }\end{array}$ \\
\hline $\begin{array}{l}\text { 3. Migration of vascular } \\
\text { smooth muscle }\end{array}$ & N/A \\
\hline 4. Intimal thickening & N/A \\
\hline $\begin{array}{l}\text { 5. Hypertrophy/hyperplasia of } \\
\text { vascular smooth muscle }\end{array}$ & $\begin{array}{l}\text { Hypertrophy/hyperplasia } \\
\text { of airway smooth muscle }\end{array}$ \\
\hline 6. Collagen deposition & Collagen deposition \\
\hline 7. Fibrosis & Fibrosis \\
\hline $\begin{array}{l}\text { 8. Increased vascular respon- } \\
\text { siveness in vitro }\end{array}$ & $\begin{array}{l}\text { Increased airway respon- } \\
\text { siveness in vitro? }\end{array}$ \\
\hline $\begin{array}{l}\text { 9. Increased vascular respon- } \\
\text { siveness in vivo }\end{array}$ & $\begin{array}{l}\text { Increased airway respon- } \\
\text { siveness in vivo }\end{array}$ \\
\hline $\begin{array}{l}\text { 10. Regression of remodel- } \\
\text { ling? }\end{array}$ & $\begin{array}{l}\text { Regression of remodel } \\
\text { ling? }\end{array}$ \\
\hline
\end{tabular}
N/A: not applicable.

asthma, or which outcome variables were most appropriate to measure.

In table 2, the parameters used in the International Study of Infarct Survival (ISIS) trials are shown, together with some suggestions for the design of the "ideal" comparable trial in asthma patients. One particularly useful example of the need for researchers in the respiratory field to follow developments in the cardiovascular area has arisen since the meeting. In a recent publication by O'BRIEN et al. [2] the current approaches to therapeutic intervention in atherosclerotic coronary arteries have been questioned. This study shows that

Table 2. - Comparison in design of clinical trials investigating treatments for asthma and vascular diseases

\begin{tabular}{ll}
\hline Vascular diseases & Asthma \\
\hline $\begin{array}{l}\text { Outcome measured } \\
\text { Reinfarction or death }\end{array}$ & $\begin{array}{l}\text { Hospital readmission? } \\
\text { Puffs of bronchodilator? } \\
\text { Change of FEV } \\
\text { of life? }\end{array}$
\end{tabular}

Duration of trial

5 yrs e.g. ISIS At least 3 yrs

Subjects

$11,000-44,000$ (in ISIS trials) No more than 200 at present - should be increased

Example

ISIS trials HAAHTELA et al. [1]

$\mathrm{FEV}_{1}$ : forced expiratory volume in one second; ISIS: International Study of Infarct Survival 
drugs effective in acute proliferative lesions in animal models fail to prevent restenosis of coronary arteries, suggesting that smooth muscle proliferations may not be a dominant feature in the human arterial lesion.

The lessons for us in the respiratory field are obvious. Most pathologists would agree that there is an increase in smooth muscle mass in the airway wall in asthma: however, whether this is due to hyperplasia or hypertrophy is still unclear and is currently under investigation in a number of laboratories (Jefferey (London, UK, Black, (Sydney, Australia), Holloway, (Wellington, New Zealand)). Until this is determined, it would seem premature to initiate significant commitment to antiproliferative therapy in asthma. This emphasizes the need to keep ahead of advances in other disease states, to ensure that these can be appraised in order to increase our understanding of asthma. This meeting initiated the process, but we feel sure that many others will follow.

\section{References}

1. Haahtela T, Jarvinen M, Kava T, Kivaranta K, Kuskinen $\mathrm{S}$, Lehtonen K. et al. Comparison of a $\mathrm{B}_{2}$ agonist, terbutaline, with an inhaled corticosteroid, budesonide in newly detected asthma. N Engl J Med 1991; 325: 388-392.

2. O'Brien ER, Alpers CE, Stewart DK, Ferguson M, Tran $\mathrm{N}$, Gordon $\mathrm{D}$, et al. Proliferation in primary and restenotic coronary otherectomy tissue. Implications for antiproliferative therapy. Cir Res 1993; 73: 223-231. 